\title{
Case of a Male Newborn with Incontinentia Pigmenti Initially Misdiagnosed as a Recurrent Skin Infection
}

\author{
Sang Ho Park, $\mathrm{MD}^{1}$, Kyung-Hwa Nam, $\mathrm{MD}^{2}$, Yo Han Ho, $\mathrm{MD}^{1}$ \\ Departments of ${ }^{1}$ Pediatrics and ${ }^{2}$ Dermatology, Presbyterian Medical Center, Jeonju, Korea
}

\section{ABSTRACT}

Incontinentia pigmenti (IP), also known as Bloch-Sulzberger syndrome, is a rare $\mathrm{X}$-linked dominant disorder that is generally lethal to males and almost always leads to death in utero. This disorder is a genodermatosis with characteristic cutaneous lesions and manifestations affecting the eyes, teeth, hair, and central nervous system. Genodermatosis is a hereditary disease caused by mutations in the nuclear factor-kappa B essential modulator gene mapped to chromosome Xq28. This gene encodes a variety of cytokines and chemokine regulators and is indispensable for protecting cells from tumor necrosis factor-induced apoptosis. Here we describe a case of male newborn with vesiculobullous cutaneous lesions over the left thigh and leg. We first considered the cutaneous lesions a skin infection, as they improved with intravenous antibiotics. However, recurrence and the need for repeated hospitalizations made us consider the differential diagnosis of IP, for which we performed a skin biopsy and chromosome analysis. The histology results were compatible with IP, that is, eosinophilic infiltration in the dermis and epidermis, and individual cell dyskeratinization. The chromosome analysis result was a normal 46, XY karyotype. Here we report the case of a male newborn with IP that manifested as multiple vesiculobullous skin lesions and was initially misdiagnosed as a recurrent skin infection.

Key Words: Incontinentia pigmenti; Genetic diseases, inborn; I-kappa B kinase

서론

색소실조증(incontinentia pigmenti)은 반성 우성(X-linked dominant)으로 유전되는 매우 희 귀한 신경 피부 질환으로 출생 시 발병률은 약 100,000 명당 1.2 명으로 알려져 있다 ${ }^{1)}$. 이전에 $\mathrm{NEMO}$ 로 알려진 IKBKG/NEMO (inhibitor of kappa light polypeptide gene enhancer in B-cells, kinase gamma/nuclear factor kappa B essential modulator) 유전자는 성염색체 Xq28에 위치하 며 이 유전자의 돌연변이가 남아에서 발병할 경우 매우 치명적이고 대부분 자궁 내에서 사망하 므로 이환된 환아는 주로 여아이다 ${ }^{2}$. 생존한 색소실조증 환아는 4단계로 구분되는 특징적인 피 부 병변을 보이며, 외배엽과 중배엽에서 유래된 중추신경계, 안구, 치아, 모발, 손톱, 유선 등에
Received: 6 May 2020

Revised: 16 June 2020

Accepted: 22 June 2020

Correspondence to: Yo Han Ho, MD

Department of Pediatrics, Presbyterian Medical Center, 365 Seowon-ro, Wansan-gu, Jeonju 54987, Korea

Tel: +82-63-230-1390

Fax: $+82-63-230-1490$

E-mail: soriyh@hanmail.net

Copyright(c)

By Korean Society of Neonatology.

All right reserved.

This is an Open-Access article distributed under the terms of the Creative Commons At tribution Non-Commercial License (http:// creativecommons.org/licenses/by-nc/4.0), which permits unrestricted non-commercial use, distribution, and reproduction in any medium, provided the original work is pro perly cited. 
서 다양한 임상증상을 나타낸다 ${ }^{3}$. 특히 출생 시, 혹은 생후 첫 2 주 내 에 홍반 수포성 병변으로 나타나는 피부 병변은 신생아 선천성 헤르 페스 감염, 수두, 수포성 농가진과 같은 감염성 피부 질환의 증상과 혼동될 수 있기 때문에 정확한 감별이 중요하다 ${ }^{4)}$. 본 저자는 출생 시 부터 홍반 수포성 피부 병변을 보인 남아를 감염성 질환으로 오인하 였고, 여러 차례 재입원 후 색소실조증으로 진단하였기에 오인했던 경험을 보고하는 바이다.

\section{증례}

재태기간 38주 4일, 출생체중 3,090 g (25-50백분위수), 남자 환 아로 본원 분만실에서 질식분만으로 태어났다. 산전 초음파상 이 상 소견 없었던 환아로 Apgar 점수는 1분 9점, 5분 10점이었고 조기 양막 파수의 증거는 없었으며 분만 시 특이 소견 없었다. 출생 당시 왼쪽 허벅지, 다리에 다수의 수포성 병변이 관찰되어 패혈증 및 피 부 감염성 질환에 대한 검사 및 치료를 하기 위하여 본원 신생아중 환자실에 입원하였다. 산모 나이 32세로 특별한 기저질환 및 가족 력은 없었고, 임신 중 약물 복용이나 감염력은 없었다. 산전 검사상 항문에서 채취한 검체에서 Group B streptococcus 양성으로 분만 4 시간 전 항생제를 투여하였다. 이번 출산 이전에 한 번의 유산 이외 에 분만력은 없었다. 본원 신생아중환자실 입원 시 시행한 신체검사 에서는 체중 $3,090 \mathrm{~g}$ (25-50백분위수), 신장 $49 \mathrm{~cm}$ (50백분위수), 두 위 $35 \mathrm{~cm}$ (75-90백분위수)로 측정되었고, 활력징후는 체온 $36.8^{\circ} \mathrm{C}$, 맥박 150회/분, 호흡 50회/분이었다. 청진상 폐음과 심음에 이상 소 견 없었고, 복부 촉진상 간, 비장 비대도 관찰되지 않았다. 피부 소 견상 왼쪽 겨드랑이와 옆구리에 갈색의 색소침착이 관찰되었고, 왼

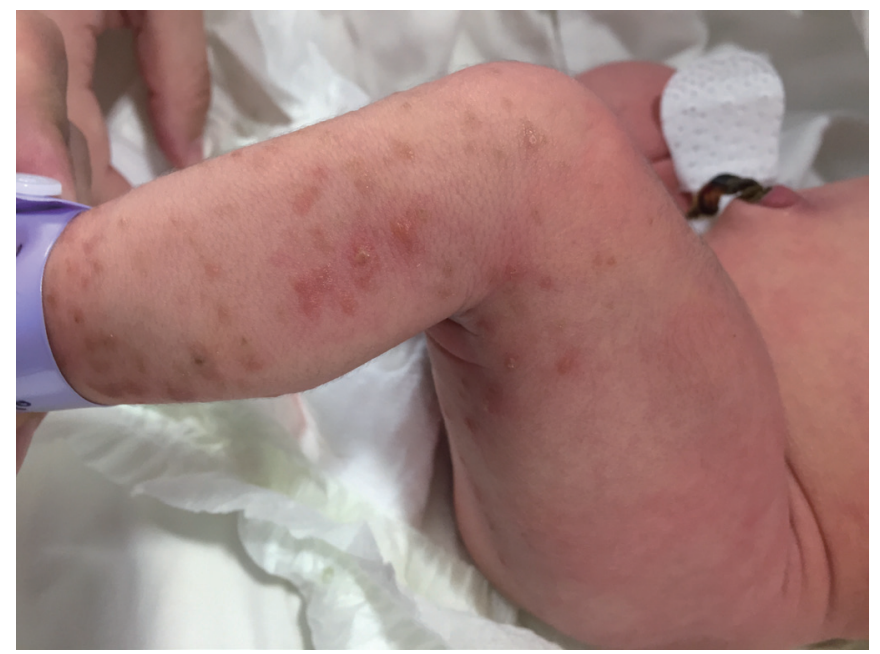

Figure 1. On the 4 th day, clustered erythematous vesicles and light brownish macules are visible along the Blaschko line on the left extremities.
쪽 허벅지와 다리에 선상의 수포성 병변 및 갈색 색소 침착이 관찰 되었다.

첫 번째 입원 당시 시행한 혈액 검사상 백혈구 $13,300 / \mathrm{mm}^{3}$ (호중 구 $68.9 \%$, 림프구 $19.3 \%$, 단핵구 $5.6 \%$, 호산구 $3.9 \%$ ), 혈색소 17.3 $\mathrm{g} / \mathrm{dL}$, 적혈구 용적률 $50.2 \%$, 혈소판 $168,000 / \mathrm{mm}^{3}$ 이었고 C-반응단 백질 $0.01 \mathrm{mg} / \mathrm{dL}$ 로 혈액검사상 감염을 시사하는 소견은 없었다. 혈 액에서 시행한 toxoplasmosis, rubella, cytomegalovirus, hepes simplex (TORCH) immunoglobulin M (IgM) 검사는 모두 음성이었다. 피부 병변의 배양 검사, 혈액, 소변 배양 검사를 시행하였으며, 피부 병변의 감염 질환 감별을 위하여 피부과 협진을 시행하여 mupirocin 성분의 항생제 연고를 도포하며 경과 관찰 하기로 한 후 생후 3 일째 퇴원하였다.

퇴원 다음 날 환아의 왼쪽 겨드랑이와 사타구니, 왼쪽 허벅지에 홍반성 발진 및 수포성 병변이 추가로 발생하여 본원 신생아중환자 실에 재입원하였다(Figure 1). 두 번째 재입원 시 시행한 혈액 검사 상 백혈구 $13,800 / \mathrm{mm}^{3}, \mathrm{C}$-반응단백질 $0.06 \mathrm{mg} / \mathrm{dL}$ 로 감염을 시사 하는 소견은 없었고, 혈액, 소변 배양 검사는 음성이었으나, 첫 입 원 시 시행한 피부 병변 배양 검사상 methicillin-resistant coagulase negative staphylococcus 양성으로 확인되어 vancomycin 정주 투여 를 시작하였다. 피부과 재협진을 시행하여 임상적으로 색소실조증 의 감별이 필요하지만, 남아이기 때문에 선상표피모반이나 선상 태 선을 우선적으로 생각하고, 조직검사는 환아의 나이를 고려하여 보 류하기로 하고 mupirocin 성분의 항생제 연고와 국소 스테로이드제 도포를 시행하였다. Vancomycin 5일 정주 후 피부 병변은 갈색의 색소 침착 이외의 수포 병변은 호전되고 추가 병변이 발생하지 않아 생후 11일째 퇴원하였다(Figure 2).

퇴원 다음 날 다시 왼쪽 겨드랑이와 왼쪽 종아리에 홍반 및 수포 성 병변이 재발하여 생후 13 일째 본원 신생아중환자실에 재입원하

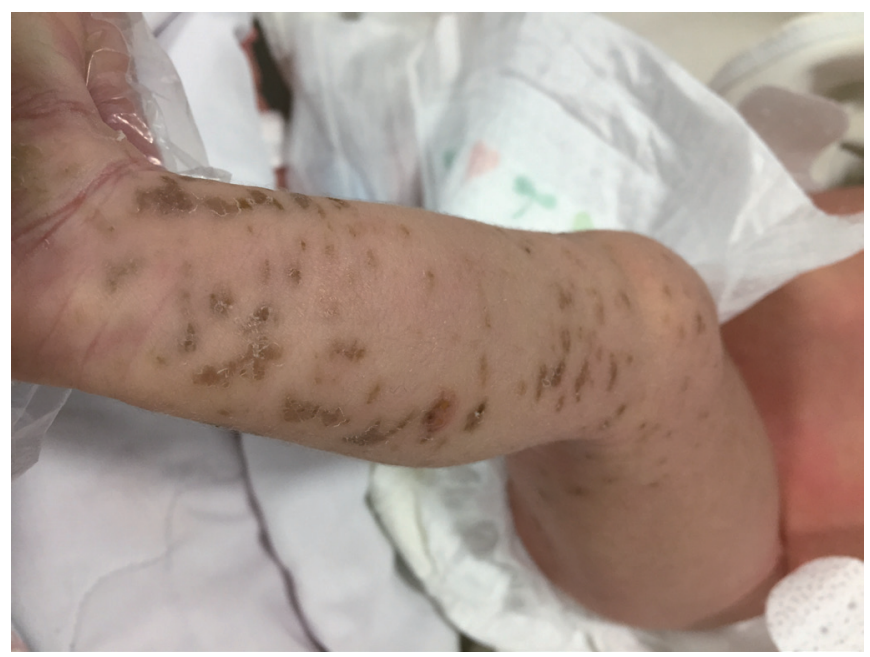

Figure 2. On the 11th day, blistered skin is replaced by crusts and dark brown colored pigmented macules on the left extremities. 
였다. 세 번째 입원 시 시행한 혈액 검사에서도 백혈구 $14,900 / \mathrm{mm}^{3}$ C-반응단백질 $0.02 \mathrm{mg} / \mathrm{dL}$ 로 감염 소견은 없었으며 herpes simplex virus IgG, varicella zoster virus IgM 모두 음성이었으나, 치료 불충 분으로 판단하여 vancomycin 정주 투여를 재개하였다. 피부과 재협 진 후 피부 병변에 질산은 습윤 드레싱을 시행하였다. Vancomycin 7 일간 정주 투여 후 피부 병변은 호전되어 생후 21일째 퇴원하였다.

환아는 퇴원 후 왼쪽 겨드랑이와 왼쪽 옆구리, 왼쪽 허벅지와 다 리에 수포성 병변이 재발하여 생후 23일째 본원 신생아중환자실에 재입원하였다. 네 번째 입원 시 시행한 혈액 검사상 백혈구 $15,700 /$ $\mathrm{mm}^{3} \mathrm{C}$-반응단백질 $0.02 \mathrm{mg} / \mathrm{dL}$ 로 감염 소견은 없었다. 피부 조직 검 사를 시행하기로 하였고, 왼쪽 하지의 수포성 병변에서 시행한 조 직 검사 결과 표피와 진피에 호산구가 포함된 수포와 해면화가 관찰 되고, 진피에서 단핵구의 침윤, 세포의 이상각화증과 keratin pearl 의 형성 등 색소실조증에서 관찰할 수 있는 소견들을 확인하였다 (Figure 3). 확진을 위하여 유전자 검사를 시행하였고, 말초 혈액을 채취하여 시행한 검사상 정상 남성 핵형인 $46, \mathrm{XY}$ 를 관찰하였다. 유 전자 수준에서의 이상 유무나 염색체의 구조적 이상을 확인하기 위 한 분자생물학적 검사는 보호자가 원하지 않아 시행하지 않았다. 색 소실조증에 동반될 수 있는 합병증의 유무를 확인하기 위해 뇌 초음 파, 청력검사, 안과 협진을 계획하였다. 환아는 입원 기간 동안 신경 학적 증상은 보이지 않았으며, 뇌 초음파에서는 특이 소견 관찰되지 않았다. 이비인후과에서 시행한 청력 검사에서 양측 모두 정상 청력 을 확인하였다. 안과 검사에서도 사시나 백내장, 망막 박리 등의 이 상 소견은 관찰되지 않았고, 생후 27 일째 퇴원하였다.

환아는 현재 생후 32 개월로 퇴원 후 타 병원에서 외래 추적 관찰 중으로, 피부 병변은 생후 60 일 이후 호전된 상태이다. 정상 발달 소

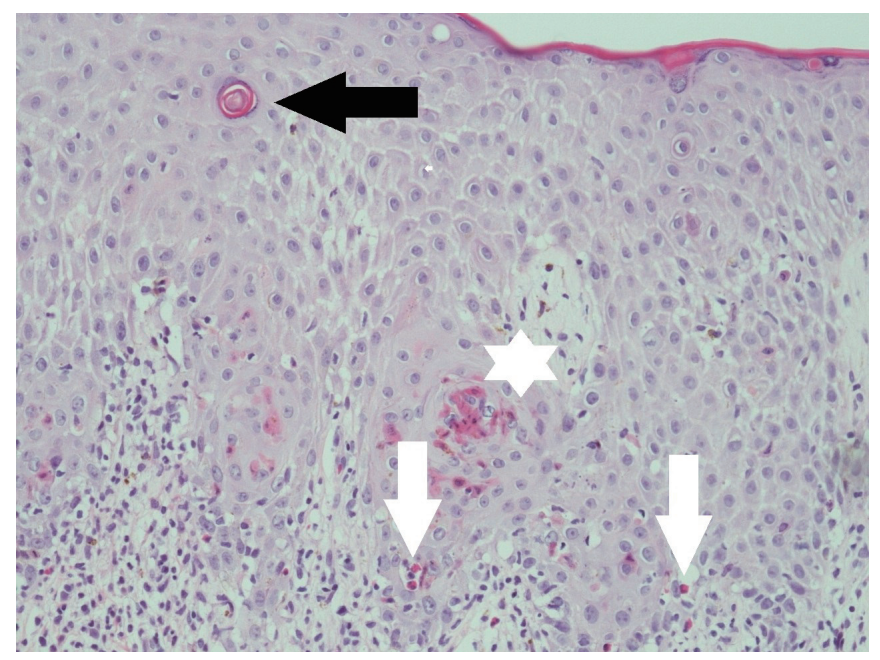

Figure 3. Histologic features of eosinophilic infiltration (white arrows) in the dermis and epidermis accompanying the vesicles and spongiosis, and individual cell dyskeratinization (asterisk) with keratin pearl (black arrow) formation (H\&E stain, $\times 200)$.
견 보이고 있어 뇌 자기공명영상검사 등의 추가 검사는 시행하지 않 았으며, 치아 발육 또한 결손 및 변형 없이 정상 소견을 보이고 있다.

\section{고찰}

색소실조증은 Garrod에 의해 1906년 처음 기술되었고, 1926년 Bloch, 1928년 Sulzberger에 의해 처음 명명되었기 때문에 BlochSulzberger syndrome으로도 불린다 ${ }^{5)}$. 색소실조증의 출생 시 발병 률은 약 100,000 명당 1.2명으로 알려져 있고 매년 27.6건의 새로운 케이스가 보고되고 있다. 케이스의 65\%-75\%는 산발적 돌연변이에 의해 발생하며, 그 외에는 유전성 원인에 해당한담.

색소실조증은 매우 드문 신경 외배엽성 질환으로 이전에 $\mathrm{NEMO}$ 로 알려진 IKBKG/NEMO 유전자의 돌연변이에 의해 발생하는 성 염색체 우성 유전 질환이다. X염색체의 장완(Xq28)에 위치하며, 약 $80 \%$ 의 환자에서 4-10번 엑손의 결실이 관찰된다. IKBKG는 nuclear factor- $\kappa \mathrm{B}(\mathrm{NF}-\kappa \mathrm{B})$ 활성 경로에 필수 단백질인 $\mathrm{NEMO} / \mathrm{I} \kappa \mathrm{B}$ kinase gamma (IKK $\gamma)$ 를 암호화하는 유전자로서 면역, 염증 반응, 세포 증식, 세포 부착, 외배엽 발생 등 다양한 생리적 기능에 관여한 다 ${ }^{7)}$. IKBKG/NEMO유전자에 돌연변이가 발생하면 NF- $\mathrm{KB}$ 의 활성 이 감소하여, tumor necrosis factor에 의한 세포 자멸에 감수성이 더 증가하여 이로 인해 광범위한 세포 자멸 반응이 나타난달. 남아의 배아는 반접합성으로 이러한 광범위한 세포 자멸 반응이 조기 태아 사망의 원인이 되지만, 여아의 배아에서는 X염색체의 비활성화로 인한 기능적 모자이크 반응으로 생존이 가능하다. 때문에 색소실조 증의 여아 발생률은 남아에 비하여 월등히 높으며 그 비율은 $37: 1$ 로 알려져 있다 ${ }^{9}$. 남아에서는 클라인펠터 증후군과 같이 여분의 X염색 체가 존재하거나, 체성 모자이크 반응, hypomorphic mutation에 의 해서 드물지만 생존이 가능하다 ${ }^{10)}$.

색소실조증의 진단기준은 1993년 Landy 와 Donnai ${ }^{11)}$ 에 의해 처 음 제안되었고, 2014년 Minic 등 ${ }^{12)}$ 이 유전학적 검사를 포함하는 개 정된 진단 기준을 발표하였다. 이후 2018년 Rosser ${ }^{13)}$ 에 의해 특징적 인 임상증상이 보완된 진단 기준을 제시하였다(Table 1).

색소실조증은 외배엽과 중배엽에서 유래된 여러 기관에서 다양 한 임상증상을 보인다. 중요한 진단 기준이 되는 특징적인 피부 병 변 외에도 중추신경계, 안구, 치아, 모발, 손톱, 유선 등에 영향을 미 친다. 대부분의 색소실조증 환아에서 발견되는 피부 병변은 출생 시, 혹은 생후 첫 2주 내 발생하여 수년에 걸쳐 나타나며 일반적으로 4단계로 나뉜다 ${ }^{11)}$. 1 단계는 약 $90 \%$ 의 환아에서 상, 하지, 두피, 몸통 에 홍반성 수포성 병변으로 출생 시, 혹은 생후 첫 2 주 내에 발생하 여 4 개월까지 점진적으로 소실된다. 2 단계는 약 $70 \%$ 의 환아에서 과 색소 침착된 농포나 가피가 생후 2주에서 6주에 발생하여 6개월까 지 소실된다. 3 단계는 약 $98 \%$ 의 환아에서 갈색의 색소 침착된 반점 
Table 1. Proposed Revision of Rosser's Incontinentia Pigmenti Diagnostic Criteria ${ }^{21)}$

Major criteria
Typical IP skin changes along the lines of Blaschko
Vesiculo-bullous
Verrucous
Hyperpigmented
Atrophic/hypopigmented
Minor criteria
CNS anomalies
Ocular anomalies
Dental anomalies
Hair abnormalities
Nail abnormalities
Palate abnormalities
Nipple and breast abnormalities
Multiple male miscarriages
Typical skin histopathologic findings

Additional conditions to confirm an IP diagnosis

No evidence of IP in a first-degree female relative: If no IKBKG mutation data available, require two or more major criteria OR one major and one minor criterion to confirm diagnosis

Confirmed IKBKG mutation with any major or minor criterion confirms diagnosis

Evidence of IP in a first-degree female relative: Requires one major criterion OR two minor criteria

Eosinophilia and skewed X-chromosome inactivation support the diagnosis in all cases

Abbreviations: IP, incontinentia pigmenti; CNS, central nervous system; IKBKG, inhibitor of kappa light polypeptide gene enhancer in B-cells, kinase gamma.

이 피부가 접히는 부위와 몸통에 주로 나타난다. 생후 12 주에서 26 주에 나타나고 병변은 성인이 될 때까지도 나타날 수 있다. 4단계는 약 $40 \%$ 미만에서 창백함, 위축성 단계로 나타나며 10 대 초반에서 성 인기에 걸쳐 점진적으로 나타난다. 각 단계의 발생 시기나 지속 기 간은 환자에 따라 차이가 있을 수 있으며, 다른 단계의 피부 병변이 동시에 나타나거나 또는 특정 단계가 나타나지 않을 수 있다.

색소실조증은 피부 병변의 단계에 따라 다른 질환을 감별해야 한 다. 1 단계의 홍반성 수포성 병변은 선천성 헤르페스 감염, 수두, 수 포성 표피박리증, 수포성 유천포창과 같은 질환의 증상과 혼동될 수 있다. 2 단계의 사마귀 모양의 과각화 단계는 선상 표피 모반, 선상 태선, 3 단계의 색소 침착 단계에서는 선상 모반 멜라닌 과다증, 4 단 계의 저색소 침착기에서는 백반증과 같은 멜라닌 저하증과 혼동될 수 있기 때문에 감별이 필요하다 ${ }^{14)}$.

색소실조증 용어는 위와 같은 특징적인 피부 병변의 조직학적 소 견에 따른 것인데, 기저 상피층의 멜라닌세포에서 유래된 멜라닌이
진피의 상부에 축적되는 3 단계 과색소 침착 단계의 특징에 따라 명 명되었다. 본 증례의 환아에서 시행한 조직 검사상 표피와 진피에 호산구가 포함된 수포와 해면화가 관찰되고, 진피에서 단핵구의 침 윤, 세포의 이상각화증과 keratin pearl의 형성 등 색소실조증에서 관찰할 수 있는 소견들을 확인 할 수 있었다.

피부 외 증상은 환아의 약 $70 \%-80 \%$ 에서 관찰된다 ${ }^{15)}$. 안구에서는 시신경 위축, 사시, 백내장, 포도막염, 망막 박리 등이 나타날 수 있 고, 치아에서는 무치증, 발육 부전이 나타날 수 있다. 탈모, 눈썹, 속 눈썹의 발생 이상이 나타날 수 있고, 조갑 이상, 부유두 발생이 동반 될 수 있다. 약 $30 \%$ 의 색소실조증 환아에서 중추신경계 이상이 발 생할 수 있으며, 단순 경련 증상부터 소두증, 뇌경색, 경직성 마비, 정신 지체, 심각한 운동성 장애까지 다양한 증상이 발생할 수 있다.

중추신경계 이상이 동반될 경우 심각한 후유증을 남길 수 있기 때 문에 색소실조증의 전형적인 피부 병변이 관찰될 시에는 신경학적 증상이 관찰되지 않더라도 가능한 한 빠른 시일 내에 뇌 자기공명영 상검사를 시행하여 중추신경계의 병변 유무를 확인하고, 발달 지연 의 가능성에 대한 진단 및 상담이 필요하다 ${ }^{16)}$. 2013년 Kim 등기은 색 소실조증의 전형적인 피부 병변을 보이고 신경학적 증상은 관찰되 지 않은 생후 4 일 여아에서 시행한 뇌 자기공명영상검사에서 다발 성 급성 뇌경색 소견을 확인하여 근 긴장도 증가와 성장 발달 지연 이 발생하기 전부터 미리 집중적인 추적 관찰을 시행 할 수 있었다. 또한 초기 평가 시에 나타나지 않았던 치아, 안구, 신경학적인 증상 이 소아청소년기 이후에도 발현될 수 있기 때문에 타과적 추적 관찰 이 지속되어야 한다 ${ }^{13,15)}$.

국내에서 최초로 보고된 남아 색소실조증 증례는 1982년 Park과 $\mathrm{Kook}^{14)}$ 에 의해 사마귀양 구진과 수포성 피부 병변과 함께 안진, 백 내장 등의 안구 이상 소견이 동반된 증례였다. 이후 1998년 Cho 등 ${ }^{18)}$ 에 의해 피부 병변과 안구 및 신경계 이상을 동반한 증례가 발표되 었고, 2006년 Kim 등 ${ }^{19)}$ 은 수포성 피부 병변과 함께 출생 후부터 3개 월까지 간헐적인 간대성 경련의 신경학적 증상이 동반된 남아 색소 실조증 사례를 보고하였다. 2006년 Kim 등디이 발표한 논문에서는 1995년부터 2005년까지 총 40명의 색소실조증 환아 중 단 2명 만이 남아였다. 2008년 Song 등20)은 유전자 검사상 정상 핵형을 보인 색 소실조증 환아의 증례를 보고하였다.

해외에서는 Hadj-Rabia 등 ${ }^{21}$ 이 2003년 발표한 논문에서 1986년부 터 1999년까지 프랑스 내 단일 의료기관의 색소실조증 환자 40 명에 대한 증례 발표에서 3 명만이 남아였다. 다른 증상 없이 피부 병변만 보인 경우, 피부 병변과 함께 편측 마비의 신경 증상이 동반된 경우, 피부 병변과 함께 안진, 경련의 신경학적 증상, 자기공명영상검사상 전두엽의 허혈성 병변이 관찰된 경우였다. 2006년 Pacheco 등22)은 9명의 색소실조증 남아의 유전자 검사상 모두 정상 핵형을 보였으 나, 1 명의 환아가 생후 7 세 때에야 경련의 신경학적 증상과 함께 치 아의 부식, 벗겨짐의 증상이 나타났음을 보고하였다. 2014년 Fusco 
등 23)은 2000년부터 2013년까지 386명의 색소실조증 증례를 조사하 였는데 이 중 37명이 남아인 것으로 나타났다. 2019년 Jaramillo 등ㅁ) 은 2004년부터 2018년까지 스페인의 두 의료 기관에서 색소실조증 으로 진단받은 13 명의 환아 모두 여아였음을 보고한 바 있다.

본 증례의 환아는 출생 시부터 몸통과 하지에 수포성 병변이 보였 으나 남아이기 때문에 색소실조증보다는 신생아 감염성 질환으로 오인하여 수차례 재입원을 해야 했고 진단이 지연되었다. 신생아의 수포성 피부 질환에 대하여 비감염성 질환, 남아에서의 색소실조증 의 발병 가능성을 염두하여 불필요한 광범위 항생제 치료를 하지 않 도록 해야 할 것이다.

\section{ARTICLE INFORMATION}

\section{Ethical statement}

The Institutional Review Board (IRB) of Presbyterian Medical Center approval for the study was received in July 2019. Retrospective data collection was approved by the IRB of Presbyterian Medical Center (IRB No. E2019-024). Written informed consent was obtained from all parents.

\section{Conflicts of interest}

No potential conflict of interest relevant to this article was reported.

\section{Author contributions}

Conception or design: S.H.P., Y.H.H.

Acquisition, analysis, or interpretation of data: S.H.P., Y.H.H.

Drafting the work or revising: S.H.P., Y.H.H.

Final approval of the manuscript: S.H.P., K.W.N., Y.H.H.

\section{ORCID}

Sang Ho Park https://orcid.org/0000-0002-5530-2458

Yo Han Ho https://orcid.org/0000-0001-7517-955X

\section{Acknowledgments}

None

\section{REFERENCES}

1. Orphanet Report Series: rare diseases collection. Prevalence and incidence of rare diseases: bibliographic data [Internet]. Paris: Orphanet; 2020 [cited 2020 Aug 12]. Available from:
https://www.orpha.net/orphacom/cahiers/docs/GB/ Prevalence_of_rare_diseases_by_alphabetical_list.pdf.

2. Fusco F, Paciolla M, Napolitano F, Pescatore A, D'Addario I, Bal E, et al. Genomic architecture at the Incontinentia Pigmenti locus favours de novo pathological alleles through different mechanisms. Hum Mol Genet 2012;21:1260-71.

3. Berlin AL, Paller AS, Chan LS. Incontinentia pigmenti: a review and update on the molecular basis of pathophysiology. J Am Acad Dermatol 2002;47:169-87.

4. Cammarata-Scalisi F, Fusco F, Ursini MV. Incontinentia pig menti. Actas Dermosifiliogr 2019;110:273-8.

5. Sulzberger MB. Uber eine bisher nicht beschriebene congenitale Pigmentanomalie [About a previously udescribed congenital pigment anomaly]. Arch Dermatol Syph (Berl) 1928;154:1932.

6. Greene-Roethke C. Incontinentia pigmenti: a summary review of this rare ectodermal dysplasia with neurologic manifestations, including treatment protocols. J Pediatr Health Care 2017; 31:e45-52.

7. Fusco F, Valente V, Fergola D, Pescatore A, Lioi MB, Ursini MV. The incontinentia pigmenti genetic biobank: study design and cohort profile to facilitate research into a rare disease worldwide. Eur J Hum Genet 2019;27:1509-18.

8. Sebban H, Courtois G. NF-kappaB and inflammation in genetic disease. Biochem Pharmacol 2006;72:1153-60.

9. Carney RG. Incontinentia pigmenti: a world statistical analysis. Arch Dermatol 1976;112:535-42.

10. Kenwrick S, Woffendin H, Jakins T, Shuttleworth SG, Mayer E, Greenhalgh L, et al. Survival of male patients with incontinentia pigmenti carrying a lethal mutation can be explained by somatic mosaicism or Klinefelter syndrome. Am J Hum Genet 2001;69:1210-7.

11. Landy SJ, Donnai D. Incontinentia pigmenti (Bloch-Sulzberger syndrome). J Med Genet 1993;30:53-9.

12. Minic S, Trpinac D, Obradovic M. Incontinentia pigmenti diag. nostic criteria update. Clin Genet 2014;85:536-42.

13. Rosser T. Neurocutaneous disorders. Continuum (Minneap Minn) 2018;24:96-129.

14. Park SS, Kook HI. A case of incontinentia pigmenti (BlochSulzberger type) in male. Korean J Dermatol 1982;20:487-491.

15. Kim BJ, Shin HS, Won $\mathrm{CH}$, Lee JH, Kim $\mathrm{KH}$, Kim MN, et al. Incontinentia pigmenti: clinical observation of 40 Korean cases. J Korean Med Sci 2006;21:474-7.

16. Ocana Jaramillo S, Del Boz J, Vera Casano A. Incontinentia pigmenti: a descriptive study of experience in two different hospitals. An Pediatr (Barc) 2020;92:3-12.

17. Kim TH, Choi YJ, Park HK, Kim CR, Lee HJ. A case of incontinentia pigmenti with multiple brain infarction. Neonatal Med 2013;20:228-32.

18. Cho MJ, Shin SM, Moon HK. A case of incontinentia pigmenti 
developed in a male newborn infant. Yeungnam Univ J Med 1998;15:381-90.

19. Kim BJ, Lee DH, Shin HS, Won CH, Lee JH, Kwon OS. Incon tinentia pigmenti in a male infant. Korean J Dermatol 2006;44: 624-6.

20. Song JY, Na CH, Chung BS, Choi KC, Shin BS. A case of a surviving male infant with incontinentia pigmenti. Ann Dermatol 2008;20:134-7.
21. Hadj-Rabia S, Froidevaux D, Bodak N, Hamel-Teillac D, Smahi A, Touil Y, et al. Clinical study of 40 cases of incontinentia pigmenti. Arch Dermatol 2003;139:1163-70.

22. Pacheco TR, Levy M, Collyer JC, de Parra NP, Parra CA, Garay $\mathrm{M}$, et al. Incontinentia pigmenti in male patients. J Am Acad Dermatol 2006;55:251-5.

23. Fusco F, Paciolla M, Conte MI, Pescatore A, Esposito E, Mirabelli $\mathrm{P}$, et al. Incontinentia pigmenti: report on data from 2000 to 2013. Orphanet J Rare Dis 2014;9:93. 